\title{
Location SECURity and ENVIRONMENTAL- InduCed Displacement: a Case Study of THE RIVERINE ISLANDS IN BANGLADESH
}

\author{
BRAD K. BLITZ
}

\begin{abstract}
This article introduces the concept of 'location security' to describe the specific relationship between place, environmental and human security. It argues that 'location security' is determined by a location's resilience to risk, understood in terms of the degree to which a specific region is protected by virtue of geographical endowments and has sufficient infrastructure to withstand and recover from the effects of environmental hazards and ensure that rights are protected. To illustrate the concept of location security, this article uses the sustainable livelihoods framework to explore actual and anticipated environmental pressures that affect the river deltas of Bangladesh, and examines the adaptation responses developed by the inhabitants of the riverine islands. A central finding of this article is that flexible migration and localised coping strategies based on acute knowledge of their local ecological and geological systems, enables the char dwellers to reduce their vulnerability. In this setting, human and environmental factors when harnessed may enhance agency to mitigate hazards.
\end{abstract}

\section{Résumé}

Cet article propose le concept de "sécurité du lieu " pour décrire les incertitudes auxquelles sont confrontés les populations de zones menaces par les chocs environnementaux et les effets complexes de leur éventuelle adaptation. On $y$ avance que la sécurité du lieu se mesure en fonction de la résilience de la zone considérée, determine par l'importance de sa protection par des subventions territoriales, par la présence d'infrastructure permettant de soutenir les risques environnementaux et de s'en remettre, et par la mesure dans laquelle les droits sont protégés.

Cet article explore les pressions environnementales actuelles et à venir au Bangladesh. On en conclut que la sécurité du lieu est déterminée par les interactions entre les considérations environnementales et humaines, au premier chefl'impact sur les moyens de subsistance, et que des migrations de formes et de durées diverses peuvent resulted de pressions environnementales, comme des pressions sociales, économiques et politiques.

\section{Introduction}

This article introduces the notion of 'location security' to describe the uncertainties facing people in environmentally threatened areas and the complex effects of their anticipated adaptation. 'Location security' recognises the interaction of multiple factors in the creation of both human and environmental vulnerabilities. It develops the concepts of vulnerability and risk as found in the literature on human and environmental security by emphasising the importance of place and agency for the protection and realisation of rights. 'Location security' is defined by a location's resilience to risk, understood in terms of the degree to which a specific region is protected by virtue of geographical endowments (topography, quality of soil, nature of human settlements), and has sufficient infrastructure to withstand and recover from the effects of environmental hazards. In this context, migration is one of several adaptive responses to location insecurity and livelihoods vulnerability where people may move both on a temporary and permanent basis in order to mitigate the effects of environmental hazards. 
To illustrate the concept of location security, this article presents a single case study of the riverine island dwellers (char dwellers) in Bangladesh. It explores the ways in which their location and relationship to their fragile ecosystem defines their access to livelihoods and also how they are placed to respond to environmental shocks, above all riverbank erosion and flooding. Developing the Sustainable Livelihoods Framework (SLF), this article explores how their specific location influences the livelihood strategies and outcomes available to individuals and households, including the prospect of migration. The SLF is used to inform the opportunities and obstacles facing char dwellers with respect to five key assets: physical, financial, natural, human, and social capital. This article concludes by identifying the ways in which char dwellers have coped with environmental stress and reviews the effectiveness of related livelihoods enhancing interventions including the Chars Livelihoods Programme.

\section{Review of Relevant Literature}

The concept of 'location security' features implicitly in region specific and country studies of environmental vulnerability. Hallie Eakin and Maggie Walser provide a preliminary discussion of 'location security' in their entry in the Encyclopaedia of Earth in which she writes that environmental vulnerability is neither an outcome nor a static internal condition but rather a dynamic property emerging from the structure of human relations, the internal attributes of specific populations and places, and the nature of social-environmental interaction'. ${ }^{1}$ Vulnerability expresses both risk and the capacity for resilience. In the context of 'location security', the specificity of place is of paramount importance in the estimation of vulnerability. Further, just as environmental impacts may be differentiated acrossand within-geographically bounded areas, for example within different parts of cities, river systems, or provincial territories, we note that adaptive responses may also be localised, ${ }^{2}$ including migration. ${ }^{3}$ Some people chose to flee following environmental disasters, while others do not.

The literature on human security also provides a basis for developing the concept of location security in its treatment of localised risk and the growing recognition of multi-causality and inter-causality in the creation of vulnerabilities. ${ }^{4}$ There is also a growing body of empirical work on compound vulnerability which is relevant to this article. For example, in the Voices of the Poor reports, the largest public opinion survey conducted with approximately 60,000 people in 60 countries, the participants' responses illustrate a complex perception of insecurity which is informed by their understanding of structural deprivation and environmental vulnerability. Respondents describe their marginality not only in terms of their inadequate living conditions or the poor quality of available infrastructure but in relation to the environmental risks they face given their physical location. In such accounts, their settlement in unsustainable locations underscores their insecurity and deepens their poverty. ${ }^{5}$ More recent studies by the Asian Development Bank (ADB) further identify a strong connection between location and vulnerability to flooding. For example in their report on climate risks, the ADB calls attention to the concentration of poor households in low-lying areas including swamps and wetlands where populations are exposed to potential storm and tidal surges. ${ }^{6}$ Susmita et. al. (2009) similarly project forward to describe how both development efforts and natural weather events are creating unsustainable situations. They argue that climate-induced extreme weather events, may give rise to storm surges which will bring unmanageable levels of flooding to concentrated pockets of poor people in under resourced cities. ${ }^{7}$ Other comparative studies have further called attention to the risks posed by poor quality housing and human settlement, on the edges of megacities. ${ }^{8}$

A further body of literature introduces the prospect of migration explicitly. Alam describes the relationship between environment and displacement and the geo-political challenges this raises in the context of Bangladesh and India. He argues that the combined effects of demographic pressures on land and water resources, environmental change and rapid development, have given rise to widespread landlessness, unemployment, declining wages and income, growing income disparities and degradation of human habitat which have encouraged the out-migration of millions of Bangladeshis to India. ${ }^{9}$ Others have similarly found that a key driver of migration in South Asia is the breakdown of eco-system dependent livelihoods as a result of both human and environmental factors. ${ }^{10}$ In this context climate change, which is associated with the increased frequency of extreme weather conditions, is considered to be a 'risk-multiplier'.

The relationship between migration and location security, however, requires further examination. Some prominent scholars have contested the deterministic leaning in both the environmental and human security literature briefly described above. Gemenne, for example, argues that increased water stress-when the demand for water exceeds the available amount during a certain period or when poor quality restricts its use-can affect migration patterns in different directions and may give rise to multiple types of adaptation. ${ }^{11}$ Barnet similarly found that many would be migrants do not necessarily leave situations where they are at risk but rather invest in satisfying their basic needs. ${ }^{12}$ Hence while migration is one means of adaptation, it is not necessarily the preferred option for many living in threatened 
environments. Gemenne therefore suggests it is helpful to differentiate between types of migrant in order to describe both the push factors and potential duration of the migration. He suggests using the term environmental migrants, to describe those whose movement he claims is voluntary and pro-active. By contrast, the term environmental displacees, describes those whose movement is forced and reactive. Similarly Renaud et al. (2010) identify three main categories of environmental migrant: environment emergency migrant where one flees to save one's life; environmentally motivated migrant where a migrant decides not to return or decides against taking up an alternative livelihood in impacted area choosing to flee instead; and an environmentally forced migrant where following slow and ineffective attempts at recovery, the migrant does not return or if alternative livelihood would be delayed or was impossible-or if the impacted area no longer exists, the migrant flees. ${ }^{13}$

While situating the analysis within the above literature, this article synthetically contributes to both the writings on environmental displacement and human security. It revisits through an empirical case study how location and agency impact on vulnerability and offers policy considerations in combating those.

\section{Conceptual Framework}

This study uses the Sustainable Livelihoods Approach (SLA) to explore the ways in which char dwellers have responded to the environmental shocks associated with river bank erosion and flooding. Although the SLA was originally designed by the UK Department of International Development (DFID) to improve the agencies capacity to contribute to poverty elimination, ${ }^{14}$ it has proved a remarkably flexible framework to analyse complex environmental challenges and their impact on livelihoods. ${ }^{15}$ For the purposes of this study, livelihood is defined in broad terms to include the capabilities, assets (including both material and social resources) and activities required for a means of living. Borrowing from DFID's definition, we describe a livelihood to be sustainable 'when it can cope with and recover from stresses and shocks and maintain or enhance its capabilities and assets both now and in the future, while not undermining the natural resource base.' ${ }^{.6}$

A central feature of the SLA is the inclusion of five related asset types. These have been described in terms of types of capital which can be converted to inform strategies to affect livelihood outcomes which in turn may reduce vulnerability. The five assets are described as natural, social, physical, human and financial forms of capital. The strength of the SLA is its holistic nature. It takes into account not only threats, challenges and weaknesses (as part of the vulnerability context), but also improvised strategies, opportunities, and strengths of individuals, households, and /or communities. The framework also provides for micro to macro level analyses of the contexts in which these strategies must be implemented, including links between micro and the macro institutional and policy making and delivery structures, and processes. ${ }^{17}$

For the purposes of this article, location security is defined as a location's resilience to risk, understood in terms of the degree to which a specific region is protected by virtue of geographical endowments (topography, quality of soil, nature of human settlements), and has sufficient infrastructure to withstand and recover from the effects of environmental hazards. What makes a location secure is a mix of both natural and human factors. For environmentally threatened populations, the degree to which they can enhance their sustainability by mobilising their assets necessarily informs their sense of security. In the context of environmental vulnerability, the preservation of natural and human capital (above all health) is especially significant since these are frequently among the most vulnerable assets.

Factors which inhibit location security include the destruction of natural capital and the loss of eco-dependent livelihoods as a result of deforestation, and the resulting ground water withdrawal and flooding, heat stress, poor housing and sanitation, soil erosion and infrastructure development. One of the most dramatic sources of natural capital depletion is in the construction of major infrastructural development projects in the form of dams, hydro-electric and energy production plants. During the last 50 years, in India alone, an estimated 25 million have been displaced by development projects. In that same period, development projects in China have displaced more than 40 million people, including 13.6 million in the past 15 years. ${ }^{18}$ Most notably, China's Three Gorges Dam on the Yangtze River, which stretches across Sandouping, Yichang, and Hubei provinces was built in an earthquake zone and its construction required the drowning of farmland, cities and towns, and the involuntary relocation of 1.3 million people. The process of creating the dam came at considerable psychological stress, ${ }^{19}$ and reportedly caused massive subsequent ecological damage downstream where further deforestation and coastal erosion rendered other areas unsustainable. ${ }^{20}$

Other causes of the depletion of natural capital include rapid urbanisation and unsustainable settlement in regions where there is inadequate urban planning and coordination of civic services. The rapid expansion of megacities in much of South Asia, East Asia and China has forced millions of migrants to exist in polluted and unsanitary living quarters, often in low lying coastal areas where infrastructure is lacking, leaving them vulnerable to flooding and displacement. Those most at risk include the urban poor concentrated in 
flood prone areas in and around Ho Chi Minh City, Dhaka, Kolkata, and Manila.

Further, the extensive demand for timber and wood has led to high rates of deforestation and has put great strain on local living conditions for millions of people across the Asia-Pacific region. While Asia contains only 16 percent of the world's remaining tropical forests, approximately 25 percent of global forest loss is caused by deforestation, ${ }^{21}$ in order to clear the ground for substitute income generating cultivation and production including other forms of agriculture, palm oil and biofuel production. Some argue that the net effect has accelerated vulnerabilities since deforestation impacts on livelihoods by affecting watersheds. ${ }^{22}$ Examples of how deforestation has contributed to environmental pressures which have prompted the out-migration of vulnerable people are illustrated by the after effects of the droughts in Yunnan China and the drying out of the Paguyaman River in North Sulawesi, Indonesia. ${ }^{23}$

The distinct pressures mentioned above have given rise to different adaptation and mitigation strategies including seasonal and permanent migration as well as collective responses. Some governments have taken steps to protect their populations from climate-induced hazards, most notably the Maldives which established a sea wall around the main island that is claimed with protecting the population of Male from the 2004 Tsunami. Some countries, such as Thailand have also put in place schemes to reduce the effects of land subsidence; ${ }^{24}$ others such as Vietnam have focused on providing alternative livelihoods to resettled populations.

For analytical purposes, we may distinguish between the following location specific vulnerabilities.

\section{The Riverine Chars of Bangladesh}

'Char' is the Bengali word for the sand and silt land masses which form the riverine islands in the Jamuna, Padma and the Meghna rivers. Chars play a critical role as cultivable areas in what is a densely populated state. An estimated 6.5 million people (approximately 5 per cent of the Bangladeshi population) live on chars. ${ }^{25}$ Even in country where an estimated 40 per cent of the population are poor, ${ }^{26}$ char dwellers are among the poorest of the poor and have had to adapt to survive in the ecologically fragile delta and river systems. Sarker et al. (2003), note that while chars provide an environment which is used for subsistence agriculture, animal husbandry and fishing they are difficult to access and form an extremely dynamic environment as a result of frequent and intensive flooding and erosion. ${ }^{27}$ Three of the most precarious areas are the South West region and Sunderbans-the largest single block of tidal halophytic mangrove forest in the world-the Meghna Estuary region, and South East Chittagong division.

In response to the above environmental threats, migration has become a feature of life for char dewellers. Riverbank erosion is estimated to displace 600,000 people every year. ${ }^{28}$ Poncelet argues that riverbank dwellers are at risk of 'involuntary migration', landlessness and homelessness. She claims that since 2003 approximately 135,632 families became homeless due to riverbank erosion and maintains that landlessness also results from the reallocation of (un) usable resources, noting that since 1973 , over 158,780 hectares has been lost to riverbank erosion. ${ }^{29}$ This involuntary migration stands in sharp contrast to the adaptation strategies which have sustained urban migrants in Bangladesh. In their study of displaced urban dwellers, the IOM recorded that 83 per cent of respondents cited unemployment due to frequent floods as the primary cause for the out-migration of a household member who settled in a city nearby. The out-migration, however, served to strengthen the position of the household back home since remittances were used not only to buy food but also capital investments, including the repair of homes. ${ }^{30}$ By contrast, char dwellers who migrate often move to nearby and equally vulnerable chars where there is no possibility of generating a surplus required for remittances. Sarker et al. (2003) describe the specific locational challenges for char dwellers as a result of environmental pressures and eventual displacement:

People displaced by char erosion have no other alternative than to settle on accreting char land elsewhere, creating a typical social and economic char environment. The economics of the char lands are largely based on agriculture, fishing and livestock-rearing. Education, health and extension services and support to cope with the calamities of flood and erosion are minimal. This not only results in individual misery, but also in unrealized potential of resources on the chars. ${ }^{31}$

We also note that by relocating from one char to another, char dwellers remain trapped in a subsistence level existence as landless farmers, fishermen or agricultural producers. Char dwellers may have access to these riverine lands but do not actually hold any natural capital and as a result are tied to their environment.

Nonetheless, char dwellers remain committed to the river deltas. In some 350 interviews conducted over 8 chars, Marie-Pierre Arseneault (2012) found that in spite of the risks, most people wished to remain on the chars. While several men interviewed had the opportunity to move away for work, such movements were temporary and the vast majority of permanent migrations were from one char to 
Table 1-Location Specific Vulnerabilities

\begin{tabular}{|c|c|c|c|}
\hline Location & Category Affected & Environmental Pressures & Vulnerabilities \\
\hline Megacities & Urban migrants & $\begin{array}{l}\text { Heat stress, sanitation and } \\
\text { water, housing, disease, } \\
\text { flooding. }\end{array}$ & $\begin{array}{l}\text { Destruction of natural and } \\
\text { human capital as a result } \\
\text { of pollution, over crowding, } \\
\text { public health risk, fatalities. }\end{array}$ \\
\hline $\begin{array}{l}\text { Tropical forests/mountain } \\
\text { areas }\end{array}$ & Forest dwellers & $\begin{array}{l}\text { Deforestation as a result of } \\
\text { over logging; glacial melting. }\end{array}$ & $\begin{array}{l}\text { Destruction of natural and } \\
\text { human capital as a result } \\
\text { of changes to watershed, } \\
\text { drought and flooding, } \\
\text { increase in water and air- } \\
\text { borne diseases, infestation. }\end{array}$ \\
\hline Himalayas & Mountain dwellers & $\begin{array}{l}\text { Glacier retreat; increased } \\
\text { flooding, heavy precipita- } \\
\text { tion as a result of climate } \\
\text { change }\end{array}$ & $\begin{array}{l}\text { Destruction of natural and } \\
\text { human capital as a result } \\
\text { of displacement following } \\
\text { soil erosion, crop destruc- } \\
\text { tion, damage to farming, } \\
\text { increase in water and air- } \\
\text { borne diseases, infestation. }\end{array}$ \\
\hline Pacific basin, Pacific islands & Coastal Villagers & $\begin{array}{l}\text { Flooding due to cyclones, } \\
\text { sea-level rise, salinity, soil } \\
\text { erosion, as a result of cli- } \\
\text { mate change }\end{array}$ & $\begin{array}{l}\text { Destructition to natural, } \\
\text { human and social capital } \\
\text { following fatalities, damage } \\
\text { to agricultural livelihoods, } \\
\text { fishing, increase in infec- } \\
\text { tious water and airborne } \\
\text { diseases e.g. malaria. }\end{array}$ \\
\hline Pacific islands & Low Lying Island dwellers & $\begin{array}{l}\text { Flooding due to cyclones, } \\
\text { sea-level rise, salinity, soil } \\
\text { erosion, as a result of cli- } \\
\text { mate change }\end{array}$ & $\begin{array}{l}\text { Destruction of natural and } \\
\text { social capital as a result of } \\
\text { statelessness; and destruc- } \\
\text { tion of livelihoods. }\end{array}$ \\
\hline Inland & Farmers & $\begin{array}{l}\text { Glacier retreat; increased } \\
\text { flooding, heavy precipita- } \\
\text { tion as a result of climate } \\
\text { change; flooding due to } \\
\text { cyclones, sea-level rise, } \\
\text { salinity, soil erosion, as a } \\
\text { result of climate change }\end{array}$ & $\begin{array}{l}\text { Destruction of natural capital } \\
\text { as a result of changes to } \\
\text { watershed, drought and } \\
\text { flooding; displacement, soil } \\
\text { erosion, crop destruction. }\end{array}$ \\
\hline $\begin{array}{l}\text { Coastal and riverbank com- } \\
\text { munities; low lying island } \\
\text { nations }\end{array}$ & Fishermen & $\begin{array}{l}\text { Flooding due to cyclones, } \\
\text { sea-level rise, salinity, soil } \\
\text { erosion, as a result of cli- } \\
\text { mate change }\end{array}$ & $\begin{array}{l}\text { Destruction of natural capital } \\
\text { as a result of pollution, } \\
\text { flooding, loss of fish and } \\
\text { related livelihoods. }\end{array}$ \\
\hline
\end{tabular}

another where they were still exposed to environmental risk, sometimes greater than in their previous setting. ${ }^{32}$

In spite of their fragile habitat, the char dwellers have developed a system of environmental adaptation suited to their limited assets and which draws upon their understanding of the natural processes of accretion and sediment dynamics. In response to flooding and coastal erosion, the char dwellers navigate the geological contest between loss of land from riverbank erosion and the emergence of new land through the process of accretion and move from char to char as necessary. For some, the possibility of returning to their reconstituted island home provides a source of security. ${ }^{33}$ Writing on the development of chars and Mohammad
Arifur Rahman and Md. Munsur Rahman of the Institute of Water and Flood Management, Bangladesh University of Engineering and Technology, describe how chars form over a 12-15 year period, during which time char dwellers engage in several different livelihoods from cultivating ground nuts to preparing the land for rice production. ${ }^{34}$ They describe a tradition of adaptation and flexibility which includes exploiting the natural processes of land accretion, migration and the rotation of crops. ${ }^{35}$ Elsewhere, Hanna Schmuck-Widmann (2001) has found that char dwellers on the Jamuna River follow strategies based on local-indigenous knowledge to produce agricultural products and rear animals. ${ }^{36}$ 
In addition to informal and traditional modes of adaptation, the government of Bangladesh, together with the UK Department for International Development (DFID) and Australian Agency for International Development (AusAID) has introduced specific programmes which aim to improve the livelihoods of char dwellers exposed to riverbank erosion and displacement. The Chars Livelihood Programme delivers both welfare and initiates human capital development efforts to support extremely poor households living on chars on the Jamuna River in Northern Bangladesh. The first stage of the programme was aimed at 90,684 households - of which 55,000 received a full package of support. Women, in particular were identified for assistance which included: i) the transfer of an initial amount of capital with could be used to purchase an income generating asset (e.g. cow, rickshaw, sewing machine), followed by further monthly stipends (over 18 months); ii) the provision of physical infrastructure including plinths to raise homesteads above the flood line, as well as latrines and tubewells to improve sanitation; and iii) the delivery of social development training and other types of technical and educational support. The programme also introduced char dwellers to village based microcredit and enterprise schemes and community-based health care. ${ }^{37}$

An independent review of the above programme recorded significant gains from both the welfare and human capital development interventions. It found that, as a result of the liverlihood enhancing aspects of the programme, some of the poor and most vulnerable households were raised above the extreme poverty threshold. Further it found that individuals supported experienced positive social benefits in addition to improved health, sanitation, and nutrition. DFID reports that at least 12,490 households (or 46,712 individuals) were been lifted above the extreme poverty threshold and more than 90,000 homes were rendered physically secure as a result of this programme. The evaluators also record further benefits including a significant reduction in the prevalence of stunting among children.

Other organisations working with international partners have focused on improving the physical security of the char dwellers. For example, the Center for Environmental and Geographic Information Services (CEGIS) and UNDP initiated a project where they placed flags to mark out sites vulnerable to river erosion as a warning to villagers. Such interventions have, however produced mixed results given the difficulties of reaching this geographically dispersed group. ${ }^{38}$ Moreover, as noted above, many char dwellers have an acute understanding of their physical environment, including the dangers it presents.

While the government of Bangladesh has been primarily concerned with the displacement of urban dwellers, it has nonetheless produced a number of relevant environmental policies, including the National Environmental Management Action Plan (1996), the National Water Policy (1999), and the National Capacity Self-Assessment (NCSA) for Global Environmental Management (2007). Walsham's 2010 report for the IOM records that environmental and climate-induced migration is now included in these policy documents and underlines that the NSCA now refers to the problems of 'displacement by river bank erosion, ruralurban migration and the potential for out-migration from coastal zones'. Further, he notes the Draft National Plan for Disaster Management (2008) makes reference to displacement and specific vulnerabilities related to migration, including wider migration and development issues such as the gendered effects of migration for families left behind. ${ }^{39}$

\section{Analysis}

The above case study illustrates the pertinence of place in our consideration of both environmental and human security. While Bangladesh is subject to many environmental stresses and hazards, the above study of the riverine islands provides a crucial insight into the ways in which the natural habitat can be made adaptable to support even the most marginal livelihoods. Although the natural environment along the river deltas is extremely fragile and threatens the lives and livelihoods of millions of char dwellers, we note that the river systems themselves are sites of adaptation by virtue of the fact that land masses both disappear and reappear following flooding and remain potentially fertile and cultivable islands. Even in the absence of physical or indeed civic and administrative infrastructure on the chars, they are potentially agriculturally rich natural environments. The deltas are thus both sites of environmental vulnerability and arguably natural resilience.

The degree to which char dwellers are able to capitalise on the potential richness of the chars is, however, constrained by their own shortage of endowments, including financial and human capital. Their homesteads are at constant risk of flooding and their health is compromised by the absence of medicines and a restricted diet. Yet, as noted in the above discussion of the Chars Livelihood Programme, such inequalities can be ameliorated as a result of welfare, livelihood and human development interventions. The success of these interventions suggests that the considerable environmental challenges facing char dwellers can be managed and made more secure.

In terms of responding to the shock of environmental hazards including riverbank erosion and flooding, the vulnerability of char dwellers is compounded by their relative isolation from Bangladeshi society and their marginalisation as landless people. Although they have developed ways 
of adapting to their natural environment, by migrating and responding to their relocation with flexible methods of farming and agriculture (e.g. rotating from ground nuts to rice), they have little or no natural capital of their own and hence may have little opportunity to move beyond the chars and river systems. For this reason, livelihood enhancement programmes including Chars Livelihood Programme are important ways of reducing complex vulnerability that results from environmental pressures and social inequalities.

The contested nature of the river habitat, as an environment where land is both lost and created from flooding, provides a unique context in which to revisit the above discussion and definition of an environmental migrant. As noted above, Gemenne and Renaud et al. have broken down the term environmental migrant to describe both the causal intention behind the act of migration and the conditions which sustain it. Arguably char dwellers could, at various points, be classified as environmental emergency migrants (who later return), or environmentally motivated migrants though, as Arseneault's research suggests that they are unlikely to fall into the category of the environmentally forced migrant who leaves permanently. The case of the char dwellers therefore illustrates the ways in which agency features in response to environmental threats and the importance of livelihoods and access to land, as some of the factors driving adaptation and migration.

As the above account records, the livelihood implications of environmental displacement in Bangladesh's river deltas are most profoundly felt among the extreme poor, landless, and remote communities which enjoyer fewer assets with which to mitigate the effects of displacement, migration and resettlement. In terms of scale and effect, it is important to note unlike rapid urbanisation and the proliferation of development-related projects in other parts of Bangladesh which may displace large numbers of people permanently, environmental displacement in the river deltas is often temporary. Again, the reasons for this are linked to not only to the limited options available to the char dwellers but also their successful exploitation of the ecological habitat.

The notion of location security helps to inform our understanding of the ways in which vulnerabilities are structured. We note that char dwellers have managed to diversify their livelihood strategies, combining agriculture, fishing, and farming due to both the richness of the river delta and their deep understanding of their natural environment and the geological processes which sustain it. They have done so because, even in the absence of much physical, financial or human capital, they enjoy the possibility of migrating within a familiar environment. We note that the context of their migration is notably different from the human-induced displacement experienced in the case of major industrial development projects, such as the large scale dams noted above where people's freedom of movement and agency is restricted.

\section{Conclusions: Reflecting on possible policy recommendations}

The above study illustrates the pertinence of 'location security' as a means to understanding the complex interplay between human and environmental security. The specific context of the riverine deltas of Bangladesh, otherwise sites of considerable environmental hazard, are home to millions of char dwellers who have developed successful systems of adaptation which allow them to continue their marginal eco-dependent existence in a fertile habitat. Although their location is itself the site of environmental stress from flooding and coastal erosion, which in turn threatens livelihoods, it is also a place of natural resilience and renewal. The char dwellers have an acute understanding of their habitat and its natural endowments, which enables them to mobilise their own limited asset base and migrate between chars in order to protect themselves from the above mentioned environmental hazards. We note that where migrants have been able to take charge of their own lives by relocating both in advance and following disasters, in contrast to those displaced by large infrastructural projects, they have often successfully protected livelihoods. When people have freedom of movement, are able to adapt, plan and exploit their knowledge of the local situation, migration is easier to manage and has less environmental impact.

The vulnerability of the char dwellers is not limited to environmental risk but is also determined by social, political, and economic inequalities which are expressed in their lack of human, financial and physical assets. For this reason, interventions such as the Chars Livelihood Programme are important initiatives to reduce vulnerability. We note that when migrants are given the opportunity to develop their human capital base, they are better placed to diversify skill sets and are less reliant on vulnerable livelihoods. Equally, advanced planning to build up local defences by raising buildings on plinths, and by investing in livelihoods diversification interventions may in the long term protect vulnerable populations from the compound effects of isolation, environmental hazards, and limited opportunities for human and natural capital development.

The success of the Chars Livelihoods Programme suggests that the considerable environmental challenges facing char dwellers can be managed and made more secure. Arguably more targeted interventions which focus on building human capital through health and nutrition programmes minimises disease and provides additional safeguards to the char islanders. Further by promoting access to 
common land, in this instance, fertile chars, the state may assist vulnerable populations which themselves have little or no natural capital and few convertible assets. For this reason, complementary development interventions which seek to protect homesteads, for example by raising them on plinths, are especially important.

\section{NOTES}

1. Hallie Eakin and Maggie L. Walser, "Human Vulnerability to Global Environmental Change," Encyclopedia of Earth, J. Cutler ed. Cleveland, (Washington, D.C.: Environmental Information Coalition, National Council for Science and the Environment, 2008). Available at: http://www.eoearth.org/article/ Human_vulnerability_to_global_environmental_change

2. See: Mozaharul Alam and MD Golam Rabbani, "Vulnerabilities and Responses to Climate Change for Dhaka," Environment and Urbanization 19, no. 1 (2007): 81-97; and, EACH FOR, General Overview Study Short version Subpackage 3, Asia Pacific. (Brussels, EACH-FOR, 2008), Available at: http://www.each-for.eu/documents/GOS_ Asia-Pacific_-_short_080510.pdf

3. Rita Afsar, "Internal Migration and the Development Nexus: The Case of Bangladesh," in Regional Conference on Migration, Development and Pro-Poor Policy Choices in Asia, 2003, 22-24, http://r4d.dfid.gov.uk/pdf/outputs/ migrationglobpov/wp-cp2.pdf ; Sarfaraz Alam, "Environmentally Induced Migration from Bangladesh to India," Strategic Analysis 27, no. 3 (2003): 422-438; U. S. De, R. K. Dube, and GS Prakasa Rao, "Extreme Weather Events over India in the Last 100 Years," Journal of the Indian Geophysical Union 9, no. 3 (2005): 173-187. Tasneem Siddiqui, "International migration as a livelihood strategy of the poor: The Bangladesh Case", in Migration and development: Pro-poor policy choices, ed. Tasneem Siddiqui, (Dhaka: The University Press, 2005).

4. Kofi A. Annan, "We the People"s the Role of the United Nations in the $20^{\text {th }}$ Century, (New York: United Nations, 2000), Available at: http://www.un.org/millennium/sg/ report/full.htm Kofi A. Annan, "Two Concepts of Sovereignty," in The Economist, 18 September 1999. Available at http://www.un.org/News/ossg/sg/stories/kaecon. html; World Bank, World Development Report 2000/2001 -Attacking Poverty: Opportunity, Empowerment and Security, (Washington, D.C.: World Bank, 2001), Available at: http:// web.worldbank.org/WBSITE/EXTERNAL/TOPICS/EXTP OVERTY/0,,contentMDK:20194762 pagePK:148956 piP K:216618 theSitePK:336992,00.html

5. See the three global reports: Deepa Narayan, Raj Patel, Kai Schafft, Anne Rademacher and Sarah Koch-Schulte, Voices of the Poor: Can Anyone Hear Us? (New York, N.Y.: Oxford University Press, 2000); Deepa Narayan, Robert Chambers, Meera K. Shah and Patti Petesch, Voices of the Poor: Crying
Out for Change (New York, N.Y: Oxford University Press, 2000); Deepa Narayan and Patti Petesch, Voices of the Poor: From Many Lands (New York, N.Y: Oxford University Press, 2002).

6. See World Bank, Climate Risks and Adaptation in Asian Coastal Megacities A Synthesis Report. (Washington, D.C.: World Bank, 2010). Available at: http://siteresources.worldbank.org/EASTASIAPACIFICEXT/Resources/226300-1287600424406/coastal_megacities_fullreport.pdf

7. Susmita Dasgupta, Benoit Laplante, Siobhan Murray, and David Wheeler, Climate Change and the Future Impacts of Storm-Surge Disasters in Developing Countries. Working Paper 182, September 2009. (Washington, D.C., Center for Global Development, 2009) 12. Available at: http://www. cgdev.org/content/publications/detail/1422836

8. World Bank, Climate Risks and Adaptation in Asian Coastal Megacities A Synthesis Report. (Washington, D.C.: World Bank, 2010). Available at: http://siteresources.worldbank.org/EASTASIAPACIFICEXT/Resources/226300-1287600424406/coastal_megacities_fullreport.pdf

9. See for example, Sarfaraz Alam, "Environmentally induced migration from Bangladesh to India", Strategic Analysis 27/3 (2003), 422-38.

10. Koko Warner, Charles Ehrhart, Alex de Sherbinin,Susana Adamo and Tricia Chai-Onn, In Search of Shelter: Mapping the Effects of Climate Change on Human Migration and Displacement. May 2009, p. iv. Available at: http://www.careclimatechange.org

11. François Gemenne, Environmental Migration (Version 11). 25 July 2008, Available from: http://knol.google. $\mathrm{com} / \mathrm{k} /$ francois-gemenne/environmental-migration/ qrmnmkeyllpq/2.

12. Jon Barnett, "Security and Climate Change", Global Environmental Change, 13/1 (2003), 7-17.

13. Fabrice G. Renaud, Olivia Dun, Koko Warner, and Janos Bogardi, "A Decision Framework for Environmentally Induced Migration", International Migration, 14/1 (2011), 5-29.

14. See 'Key Sheets for Sustainable Livelihoods: Overview', Department for International Development (DFID), available at: http://www.odi.org.uk/resources/download/2339. pdf

15. See 'Key Sheets for Sustainable Livelihoods: Overview', Department for International Development (DFID), available at: http://www.odi.org.uk/resources/download/2339. pdf

16. Adapted from Chambers, R. and G. Conway (1992) Sustainable rural livelihoods: Practical concepts for the 21st century. IDS Discussion Paper 296. Brighton: IDS, quoted in DFID, Sustainable Livelihoods Guidance Sheets 1.1:Introduction, p.1.

17. DFID op.cit. 
18. See: W. Courtland Robinson, Minimizing DevelopmentInduced Displacement, (Migration Information Source 2004). Available at: http://www.migrationinformation.org/ Feature/display.cfm? $\mathrm{ID}=194$

19. See: Sean-Shong Hwang, Juan Xi, Yue Cao, Xiaotian Feng, and Xiaofei Qiao(2007), "Anticipation of migration and psychological stress and the Three Gorges Dam project, China”, Social Science \& Medicine, 65/5, (2007), 1012-1024.

20. CEDEM (2009) "China Case Study Report-Forced migration and the Three-Gorges Dam". EACH-FOR, Available at: http://www.each-for.eu/documents/CSR_Three_ Gorges_Dam_090317.pdf

21. Billy Cheng, Forestry in Asia, (Responsible Research, 2010). Available at: http://www.responsibleresearch.com/ Forestry_in_Asia-Issues_for_Responsible_Investors.pdf

22. Ibid.

23. Working Group on Climate Change and Development (November 2007), cited in Cheng, 62.

24. World Bank, Climate Risks and Adaptation in Asian Coastal Megacities A Synthesis Report. (Washington, D.C.: World Bank, 2010). Available at: http:// siteresources.worldbank.org/EASTASIAPACIFICEXT/ Resources/226300-1287600424406/coastal_megacities_ fullreport.pdf

25. Environment and GIS Support Project for Water Sector Planning, Riverine Chars in Bangladesh: Environmental Dynamics and Management Issues. (Dhaka: University Press, 2000).

26. Department for International Development BangladeshIndependent Impact Assessment of the Chars Livelihoods Programme-Phase 1, Final Report, August 2011. Available at: https://www.gov.uk/government/uploads/system/ uploads/attachment_data/file/204635/Evaluation-chars -livelihoods-prog-bangladesh.pdf

27. Maminul Haque Sarker et al., "Rivers, Chars and Char Dwellers of Bangladesh," International Journal of River Basin Management 1, no. 1 (2003): 61-80.

28. Sarket et al. (2003). Op.cit.

29. Ibid, 13.
30. Matthew Walsham, Assessing the Evidence: Environment, Climate Change and Migration in Bangladesh. (Dhaka: IOM, 2010). Available at: http://www.reliefweb.int/rw/ RWFiles2010.nsf/FilesByRWDocUnidFilename/MCOI8AZEJE-full_report.pdf/\$File/full_report.pdf

31. Sarker et al. (2003). Op.cit.

32. Marie-Pierre Arseneault, (2012), Environmental migration in Bangladesh:The case of the char-islands, Center for Sustainable Development (CSD), University of Liberal Arts of Bangladesh (ULAB).

33. See: Shafi Noor Islam, Shilpa Singh, Hasibush Shaheed, Shouke Wei, "Settlement Relocations in the Char-lands of Padma River Basin in Ganges Delta, Bangladesh," Frontiers of Earth Science in China 4, no. 4 (December 1, 2010): 393 402, doi:10.1007/s11707-010-0122-5.

34. Mohammad Arifur Rahman and Md Munsur Rahman, "Impact of Livelihood Practices on the Char Dwellers Economic Condition in Riverine Chars: Case Studies in Bangladesh," Journal of the Bangladesh Association of Young Researchers 1, no. 1 (February 7, 2011), doi:10.3329/jbayr .v1i1.6838.

35. Ibid. p. 19

36. Hanna Schmuck-Widmann, "Facing the Jamuna River: Indigenous and Engineering Knowledge in Bangladesh" (Bangladesh Resource Centre for Indigenous Knowledge, 2001).

37. DFID (2011) op.cit.

38. Alice Poncelet, "Bangladesh Case Study Report-The Land of Mad Rivers", EACH-FOR, Environmental Change and Forced Migration Scenarios, (Brussels: EACH-FOR, 2009), Available at: http://www.each-for.eu/documents/CSR_Bangladesh_090126.pdf

39. Walsham, op.cit. 33 .

Brad Blitz is a professor of international politics and deputy dean, School of Law, Middlesex University. The author may be contacted atb.blitz@mdx.ac.uk. 
(C) Brad K. Blitz, 2014. This open-access work is licensed under a Creative Commons Attribution-NonCommercial 4.0 International License, which permits use, reproduction and distribution in any medium for non-commercial purposes, provided the original author(s) are credited and the original publication in Refuge: Canada's Journal on Refugees is cited. 
(C) Brad K. Blitz, 2014. This open-access work is licensed under a Creative Commons Attribution-NonCommercial 4.0 International License, which permits use, reproduction and distribution in any medium for non-commercial purposes, provided the original author(s) are credited and the original publication in Refuge: Canada's Journal on Refugees is cited. 
(C) Brad K. Blitz, 2014. This open-access work is licensed under a Creative Commons Attribution-NonCommercial 4.0 International License, which permits use, reproduction and distribution in any medium for non-commercial purposes, provided the original author(s) are credited and the original publication in Refuge: Canada's Journal on Refugees is cited. 